\title{
Use of Roth IRAs by young college graduates for retirement planning purposes \\ Received: 30th August, 2005
}

\section{Saul W. Adelman}

is currently the Finance Chair and Associate Professor at The Richard T. Farmer School of Business, Miami University (Ohio). His current research focuses on personal financial planning and is co-author of the text Professional Financial Planning: Insuring Economic Security.

\section{Mark L. Cross}

is the Ohio Casualty Professor of Insurance at The Richard T. Farmer School of Business, Miami University (Ohio). His current research focuses on retirement planning, examining financial strength ratings of insurance companies and efficient market theory as it applies to the insurance industry.

\begin{abstract}
The Roth Individual Retirement Account (IRA) is gathering acceptance among younger workers and financial advisers. With the right tools and ideas financial advisers can expand their client base by including, perhaps, the children of existing clients.
\end{abstract}

Keywords: $401(K)$ plans; retirement planning for young workers; Roth and traditional IRAs; saving for retirement; tax-deferred retirement plans

\footnotetext{
Saul W. Adelman

Chair, Associate Professor The Richard T. Farmer School of Business, Miami University

120 Upham Hall

Oxford, OH 45056, USA

Tel: +1513529 1578

e-mail:

adelmasw@muohio.edu
}

\section{Introduction}

In 1974 the US Congress passed the extensive pension legislation bill referred to as ERISA (the Employee Retirement Income Security Act). As a result of this legislation traditional IRAs (Individual Retirement Accounts) were created, allowing income earners to take a tax deduction for part or all of their IRA contribution for the tax year which, in turn, reduces current income taxes. In addition, the annual investment income generated in the traditional IRA accumulates on a tax-deferred basis.

When money is distributed, distributions are taxed as ordinary income since none of the value contained in the IRA was ever taxed. The exception would be the distribution of any after-tax contributions from a traditional IRA.

The primary intent of creating traditional IRAs was to allow for those either self-employed or working for employers having no pension plans to be able to save amounts for retirement on the same tax-advantaged basis as those employees with pension plans. In addition, it provided employees with employer-sponsored pension plans the opportunity to voluntarily reduce current taxable income and save additional amounts for retirement on a tax-deferred basis.

The traditional IRA, as described in Table 1, allows workers with earned income to make annual contributions to a retirement plan up to certain limits and receive favourable income tax treatment. The two eligibility requirements are that the employee must have earned income (wages, salaries, bonuses, commissions, self-employment income and taxable alimony) during the year and be under the age of 70.5 . 
- In 2004 , the maximum contribution to all of one's IRAs is the lesser of $\$ 3,000$ or 100 per cent of earned income. In 2005-2007 this increases to $\$ 4,000$ and in 2008 to $\$ 5,000$. After 2008 the limit is indexed to inflation in $\$ 500$ increments.

- Workers aged 50 and older can make catch-up contributions of an additional $\$ 500$ annually for year 2005 and $\$ 1,000$ annually for years 2006-2008.

- Workers not covered by an employer-sponsored retirement plan can make deductible contributions to traditional IRAs regardless of income level.

- In 2004 workers covered by an employer-sponsored retirement plan can make fully deductible contributions to a traditional IRA if modified adjusted gross income is for singles (married and filing jointly) $\$ 45,000(\$ 65,000)$ or less. The full deduction is phased out between $\$ 45,000$ and $\$ 55,000(\$ 65,000$ and $\$ 75,000$ if married and filing jointly). The phase-out limits gradually increase in the future.

In the 1986 Tax Reform Act, Congress made significant changes to the traditional IRA in an effort to raise tax revenues. Congress found that many IRA participants also had employer-sponsored pension/retirement plans available to them, including 401(k), 403(b), profit sharing, stock bonus, SEPs (Simplified Employee Pensions) and SIMPLE plans (Saving Incentive Match Plan for Employees). At that time Congress narrowed the eligibility requirements for the traditional IRA in order to receive favourable income tax treatment. As a result, people currently in the following categories can make tax-deferred IRA contributions:

- Single people not covered by an employer-sponsored pension/retirement plan.

- Married couples where neither spouse is covered by an employer-sponsored pension/retirement plan.

- Single people or married couples covered by an employer-sponsored pension/retirement plan, but are considered in the lower or middle income range.

One result of the IRA eligibility rule changes found in the 1986 Tax Reform Act was to discourage many employees covered by employer-sponsored plans from participating in IRAs as their contributions were no longer tax-deferred. Retirement plans such as 401(k), with tax-deferred contribution status were now preferred over the traditional IRA by many employees.

In an attempt to encourage greater employee participation in IRAs, Congress introduced the Roth IRA, effective the beginning of 1998, as an alternative to the traditional IRA. The Roth IRA has since become very popular. Unlike the traditional IRA, the annual contributions to a Roth IRA are never tax deductible and thus are tax-free when withdrawn. In addition, the investment income accumulates tax-deferred and distributions are tax free if the following two requirements are met:

- the Roth IRA has existed for at least five years;

- distributions are made for any of the following reasons:

— the participant is age 59.5 or older;

— the participant is disabled;

- the distribution is paid to a beneficiary or to the estate after the participant's death;

- the distribution is used to pay up to $\$ 10,000$ of participant's first-time qualified home buyer expenses.

Roth IRAs have generous eligibility requirements. Regardless of whether the worker participates in an employer-sponsored plan or not the 
Table 2: Comparison of Roth IRA with other tax-deferred retirement plans

\begin{tabular}{|c|c|c|c|c|c|c|}
\hline $\begin{array}{l}\text { Worker's } \\
\text { age }\end{array}$ & Year & $\begin{array}{l}\text { Roth IRA (\$)* } \\
\text { (A) }\end{array}$ & $\begin{array}{l}\text { Roth IRA (\$)* } \\
\text { (B) }\end{array}$ & $\begin{array}{l}\text { Traditional } \\
\text { IRA (\$) } \\
\text { (A) }\end{array}$ & $\begin{array}{l}\text { Traditional } \\
\text { IRA (\$) } \\
\text { (B) }\end{array}$ & $\begin{array}{l}\text { 401(k) } \\
\text { Plan (\$) }\end{array}$ \\
\hline 24 & 2005 & 3,000 & 1,500 & 4,000 & 2,000 & 4,000 \\
\hline 25 & 2006 & 3,000 & 1,500 & 4,000 & 2,000 & 4,000 \\
\hline 26 & 2007 & 3,000 & 1,500 & 4,000 & 2,000 & 4,000 \\
\hline 27 & 2008 & 3,750 & 1,875 & 5,000 & 2,500 & 5,000 \\
\hline 28 & 2009 & 3,750 & 1,875 & 5,000 & 2,500 & 5,000 \\
\hline 29 & 2010 & 3,750 & 1,875 & 5,000 & 2,500 & 5,000 \\
\hline 64 & 2044 & 3,750 & 1,875 & 5,000 & 2,500 & 5,000 \\
\hline \multirow[t]{4}{*}{65} & 2045 & 3,750 & 1,875 & 5,000 & 2,500 & $5,000^{\star \star \star}$ \\
\hline & Future value ${ }^{\star \star}$ & $1,088,186$ & 544,093 & $1,450,915$ & 725,457 & $1,450,915$ \\
\hline & Tax rate & 0 & 0 & 0.25 & 0.25 & 0.25 \\
\hline & $\begin{array}{l}\text { Future value } \\
\text { After-tax }\end{array}$ & $1,088,186$ & 544,093 & $1,088,186$ & 544,093 & $1,088,186$ \\
\hline
\end{tabular}

*Assume average and marginal federal income tax rate of 25 per cent now and in the future at retirement. Marginal federal income tax rate on taxable income between $\$ 30,000$ and $\$ 60,000$ in 2004 was 25 per cent. State and local income tax rates can vary and are not included in this paper.

${ }^{\star *}$ Assume a geometric mean return on investments of 8 per cent to be conservative. The geometric mean return on large company stocks for the period 1926-2003 was 10.42 per cent. Contributions are assumed made at the beginning of each year.

${ }^{* * *}$ Clearly, Congress will eventually raise the maximum contribution above $\$ 5,000$ but one can only guess as to how much and when. The actual dollar amount of contribution will not affect the comparison of the various plans, but simply the actual dollar amounts.

maximum annual IRA contribution can be made by single taxpayers with modified adjusted gross income of less than $\$ 95,000$ and by married couples filing jointly with modified adjusted gross income of less than $\$ 150,000$. Maximum annual contributions are phased out for singles between $\$ 95,000$ and $\$ 110,000$ and for married couples between $\$ 150,000$ and $\$ 160,000$. Thus, married couples with modified adjusted gross incomes over $\$ 160,000$ are not eligible for a Roth IRA. In addition, unlike a traditional IRA, contributions to a Roth IRA can be made after age 70.5 and the maximum distribution rules that apply to pensions, retirement and traditional IRAs after 70.5 do not apply to Roth IRAs. It is not necessary to start withdrawing funds from a Roth IRA at age 70.5.

\section{Roth IRA vs other investments}

The purpose of this paper is to examine under what circumstances, if any, college students entering the work force would be better served by investing in a Roth IRA as opposed to the more traditional, tax-deferred retirement plans such as the 401 $(\mathrm{k})$ and traditional IRAs.

Table 2 shows the after-tax dollars available for retirement under a Roth IRA and alternative tax deferred retirement plans such as the $401(\mathrm{k})$ and the traditional IRAs. The assumptions are that at the beginning of 2005 a 24-year-old single college graduate has taken a job with a large firm making a starting salary of $\$ 40,000$ per annum. The firm provides a $401(\mathrm{k})$ plan for their employees. The employee has the option to put the maximum annual IRA contribution either into a Roth IRA, a traditional IRA or the company's 401(k) plan. The maximum limit on elective deferrals to a $401(\mathrm{k})$ is determined by the Internal Revenue Service and is $\$ 14,000$ in 2005 ( $\$ 18,000$ for workers over age 50). The employer salary match could also impact the amount of employee contributions. An employer salary match of 3 per cent, depending on the type of 
plan, could limit employee tax-deferred contributions to 3 per cent of salary $(\$ 40,000)$ or $\$ 1,200$ in the present example.

For comparison purposes and to simplify the discussion, first assume a $\$ 4,000$ contribution is made to the Roth IRA ( $\$ 3,000$ after-tax in column A), the traditional IRA (column A) and the 401(k) plan in 2005. Using a marginal federal income tax rate of 25 per cent, the after-tax contribution to the Roth IRA is $\$ 4,000 \times(1-0.25)$ or $\$ 3,000$. Assume the contributions to the other plans are all tax-deferred and thus $\$ 4,000$ is deposited in each. Starting in year 2008 the maximum contribution increases to $\$ 5,000$. The after-tax Roth IRA contribution is $\$ 5,000=(1-0.25)$ or $\$ 3,750$.

In reality most $401(\mathrm{k})$ plans are set up to provide an employee salary match up to $2-3$ per cent of salary to encourage employee participation. Thus, in Table 2 the amount being contributed to the $401(\mathrm{k})$ plan is actually part employee and part employer amounts. Assuming over one's working life that half the $401(\mathrm{k})$ contributions are by the employee then to fairly compare $401(\mathrm{k}) \mathrm{s}$ with IRAs, the actual IRA contributions must be reduced by half. Thus, the employee contributes $\$ 2,000$ to the $401(\mathrm{k})$ plan and $\$ 2,000$ to the traditional IRA (column B) and $\$ 2,000(1-0.25)=$ $\$ 1,500$ after-tax to the Roth IRA (column B).

\section{RESULTS AND CONCLUSIONS}

As seen in Table 2, from a dollars and cents case, the decision to invest in a Roth IRA over a traditional IRA is a function of the marginal federal income tax rate at the time of contribution compared with the tax rate when the money is withdrawn (preferably at retirement). In Table 2 if the traditional
IRA amount of $\$ 1,450,915$ under column $\mathrm{A}$ is withdrawn in annual annuity payments, which are taxed at an average rate of 25 per cent, the amount left after taxes equals that of the Roth IRA of $\$ 1,088,186$ under column A. Withdrawing the entire $\$ 1,450,915$ today in one lump sum would impose a tax rate of 35 per cent at 2004 tax rates and leave an amount less than that of the Roth IRA. If one annuitised today $\$ 1,450,915$ for a single life annuity with no refund feature on a 65-year-old male (female) the annual retirement annuity would be approximately $\$ 116,227$ $(\$ 98,868)$. At 2004 income tax rates such income would be taxed at a marginal tax rate of 28 per cent. The marginal tax rate could be even higher if this annuity income is added on top of a person's other retirement income. Of course, the exclusion ratio must be applied to annuity payments to recapture any previously taxed contributions on a non-taxable basis.

The Roth IRA becomes a preferable retirement tool over the traditional IRA if the tax rate at contribution is less than the tax rate at retirement. The greater the difference the more advantageous the Roth IRA is.

One can see in Table 2 that the salary matching $401(\mathrm{k})$ plan is vastly preferable on an after-tax future value basis to either of the IRA plans. The $401(\mathrm{k})$ value is $\$ 1,088,186$ compared with the $\$ 544,093$ under columns B for the IRA plans. The average tax rate on the $401(\mathrm{k})$ plan income at retirement would have to be approximately 62 per cent to generate after-tax results $(\$ 544,093)$ equal to the Roth IRA. The tax rate on retirement income received must be 37 per cent or greater than the rate at the time of contribution to make the Roth IRA preferable to the $401(\mathrm{k})$ investment.

In Table 2, if the graduate had started a Roth IRA at an early age (12-14) 
when paying little or no taxes, the Roth IRA would be advantageous over the traditional IRA since the after-tax Roth IRA contribution would be very close to the before-tax contribution and the larger future value would be tax-free at retirement. Assume in the earlier years the students have no $401(\mathrm{k})$ plans available to them since they normally must be a full-time employee to be eligible for $401(\mathrm{k})$ participation. In the years leading up to graduation and a full-time job, the student's marginal tax rate will likely be in the 10 per cent range. The federal tax rate on taxable income from $\$ 0$ to $\$ 7,000$ is 10 per cent in 2004. Thus, a student could realistically contribute to a Roth IRA for the first 5-10 years of their working life while being subject to low tax rates.

The rule of thumb is that a Roth IRA is preferable to other tax-deferred retirement plans (assuming no employer matching contributions) as long as the participant's current marginal income tax rate is less than the average tax rate on the funds when withdrawn. As the student's income grows throughout their working life at some point the current marginal income tax rate on their earnings will probably exceed the expected average rate at retirement and contributions to a Roth IRA should cease. At that point tax-deferred retirement plans such as traditional IRAs become more economically desirable.

If funds are drawn out of IRAs before retirement the marginal tax rate on those funds can become quite large. All or part of the funds in the case of a Roth IRA would be added on top of other current income and may also be subject to an additional 10 per cent penalty. Thus, if one anticipates withdrawing funds before retirement, the Roth IRA probably becomes more advantageous over the traditional IRA since the tax rate applied to the traditional IRA at withdrawal potentially is very high.

When compared with other after-tax investments such as real estate or mutual funds, the Roth IRA is usually preferred. Like the Roth IRA such investments are made with after-tax dollars. However, the capital gains from such investments are subject to a capital gains tax rate of 15 per cent. Under certain conditions the investment gains from Roth IRAs are not taxed at all.

Since the decision to use a Roth IRA is highly dependent on current vs future income tax rates a comment on these is in order. Current income tax rates after the latest cuts in the Economic Growth and Tax Relief Reconciliation Act 2001 are historically low compared with the last few decades. With the mounting pressure on Congress to fund Social Security and Medicare and with the large current federal budget deficits looming in the future, it would appear that federal income tax rates have but one way to go in the future, and that is up. How far they rise is open to much conjecture. 